\title{
Effect of vehicular pollution on Duranta repens L. in J ammu City
}

\author{
A nil K. Raina* and Chand Bala \\ Department of Environmental Sciences, University of Jammu, Jammu-180006 (J\&K), INDIA \\ *Corresponding author. E-mail: anilkraina@yahoo.com
}

\begin{abstract}
Experimental potted plants of Duranta repens has been exposed to air pollution at major traffic crossingsAmphalla chowk, Dogra chowk, Bikram chowk, Satwari chowk of Jammu city and also inside University Campus in the department which has been taken as a reference site. Sets of 10 plants were kept at each site and analyzed for various micro morphological, anatomical and biochemical parameters to assess the changes due to air pollution Analysis of data revealed that micro-morphological parameters viz. stomatal frequency, epidermal cell frequency increased significantly while others like size of the stomata, epidermal cells and length, breadth ratio of the epidermal cells decreased significantly in plants kept at polluted location. All the anatomical parameters such as thickness of midrib region, midrib adjoining region, spongy tissue, upper epidermis and vascular bundles decreased significantly in exposed plants. Among biochemical parameters chlorophyll b decreases significantly while ascorbic acid increases significantly. Air Pollution Tolerance Index (APTI) has also been calculated and found to increase significantly in plants kept at polluted location which indicate that the Duranta repens serve as sink to air pollutants and can be effectively employed for phyto-monitoring auto exhaust pollution along the road side of the busy traffic ways.
\end{abstract}

Keywords : Air pollution tolerance index, Anatomical parameters, Biochemical parameters, Duranta repens, Micromorphological parameters, Vehicular pollution

\section{INTRODUCTION}

Today's growing population and increasing urbanization has resulted in deterioration of ambient air quality. Air is vital component of earth's environment and slight change in its composition can have varied effect on the growth, development and survival of different organisms on this planet. Vehicular exhaust, one of the important contributors of the air pollution, has increased eightfold over levels of twenty years ago while industrial pollution in comparisons has risen barely four times over the same period. India is now the world's third biggest emitter of $\mathrm{CO}_{2}$ pushing Russia into fourth place (Khergamker, 2011).

Air pollution is causing a number of changes in vegetation. Since plants are stationary and continuously exposed to chemical pollutants from surrounding atmosphere, air pollution injury to plants is proportional to the intensity of the pollution. Bio-monitoring of plants is an important tool to evaluate the impact of air pollutions. Several studies have been carried out in India to highlight the effect of air pollution on micromorphology (Palaniswamy et al., 1995; Morison, 1998; Aggarwal, 2000; Kaur, 2004), anatomy (Salgare and Rawal, 1990; Salgare and Acharekar, 1991) and biochemical (Pratibha and Sharma, 2000; Ramakrishnaiah and Somashekar, 2003; Karthiyayini et al., 2005; Gupta et al., 2009) parameters of different plant species at different places. In Jammu, stray reports are available on the effect of air pollution on plants species (Raina and Sharma, 2003; Raina and Aggarwal, 2004; Raina and Sharma, 2006; Raina and Bala, 2007). Therefore, the present work has been undertaken to assess the qualitative and quantitative effect of air pollution on Duranta repens.

\section{MATERIALS AND METHODS}

Four major traffic crossings (Amphalla chowk, Dogra chowk, Bikram chowk and Satwari chowk) have been selected on a stretch of national highway $1 \mathrm{~A}$ passing through the Jammu city as the polluted site while the Department of Environment, New University Campus has been selected as reference site for comparison purpose. Plant material of same age, selected from nursery of the Department of Floriculture and Landscaping, Govt. of Jammu and Kashmir, Talab Tillo Jammu has been planted in the pots of 8" diameter filled with prepared soil (soil + farmyard manure). For hardening and acclimatization, potted plants has been kept for one month in the nursery of the Department of Floriculture and Landscaping and then these pots has been shifted to (10 pots at each site) each polluted as well as reference sites for recording the observations. Irrigation, manuring and de-weeding of these has been done at regular intervals.

For recording the observation about 50 mature leaves (fifth from tip) have been plucked randomly from plants in the morning hours (about at 10 a.m.) and sealed in a polythene bag in the field. These leave samples have been mixed to represent the composite sample, which are 
analyzed for different parameters to represent the averages. Observations have been recorded for two years from July 2007 to July 2009 on seasonal basis (summer, monsoon, autumn and winter) and average of all the seasons has been taken to represent the results. Micro-measurements have been taken with the help of standardized ocular micrometer at $400 \mathrm{x}$ magnification by preparing a temporary mount of epidermal peeling of leaves. Temporary vertical sections of the leaves have also been prepared to record various anatomical parameters with the help of standardized ocular micrometer. Total chlorophyll contents have been determined by Hiscox and Israelstam (1979) method. For determining the Ascorbic acid, method given by Aberg (1958) has been used. $\mathrm{pH}$ and relative water contents of the leave samples have been determined by methods given by Singh (1977). Air Pollution Tolerance Index (APTI) has been calculated by using formula of Singh and Rao (1983).

Student-t test was used to find out the level of significance between the various parameters recorded from the polluted and reference sites.

\section{RESULTS AND DISCUSSION}

The data recorded on qualitative and quantitative details of various parameters of $D$. repens growing in the polluted and reference sites have been presented in the Table 1,2 and 3 . The values recorded seasonally represent the average of two years. Average of observations recorded for two years on seasonal basis has been taken to represent the results.

Perusal of table 1 revealed that micro-morphological parameters like size of stomata and epidermal cells and length/ breadth ratio of the epidermal cells decreases significantly while the stomatal and epidermal cells frequency and breadth of the epidermal cells increases significantly. The length/ breadth ratio of the stomata and stomatal index (S.I.), however, remained unaffected. Maximum significant values have been observed at Satwari and Amphalla chowk, followed by Dogra chowk and Bikram chowk.

The vehicular pollution, gaseous as well as particulate matter, is known to affect the various micro-morphological parameters. Workers like Bhiravamurthy and Kumar (1983); Chaudhari etal. (1984); Saxena (1985); Jhar (1988); Maury et al. (1989) Palaniswamy et al. (1995); Samal and Santra (2002); Raina and Sharma (2003); Kaur (2004); Raina and Aggarwal (2004); Raina and Sharma (2006); Raina and Bala (2007) have studied the effect of air pollution on different plants at various places and reported decrease in size and frequency of stomata and epidermal cells and also the stomatal index (S.I), while workers like Wagoner (1975); Yunus et al. (1982); Saxena (1985); Kumar and Jaishree (1989); Salgare and Iyer (1991);
Salgare and Swain (1991); Pal et al. (2000) and Raina and Sharma (2003) have reported increase in stomatal and epidermal cell frequency and stomatal index (S.I.) of different plant species.

The reduction in stomatal number and size may be an adaptation to decrease the amount of toxic pollutants especially gases entering the leaf which may otherwise cause injury and death of the tissue of the leaves (Sharma and Butler, 1975). In the present study, the size of stomata has decreased while the number has increased significantly. This may be an adaptation of the plant to increase the area for proper gaseous exchange.

Clogging of stomatal aperture may also take place due to plasmolysis in the guard cells and some subsidiary cells thereby resulting in the shrinking of cells as a whole. In the presence of moisture, dust particles from an alkaline environment at the stomatal opening affect the osmotic relations of the guard and subsidiary cells. As a result, plasmolysis takes place in the guard cells and some subsidiary cells and cells as a whole shrinks resulting in clogging of stomatal aperture (Krishnamurthy and Rajachidambaram, 1980). Concentrations of gases viz. $\mathrm{CO}_{2}$ and $\mathrm{SO}_{2}$ may also facilitate closing or opening of stomata. The low dose of $\mathrm{CO}_{2}$ may induce stomatal opening, while stomatal closure is facilitated by high dose of SO (Noland and Kozlowski, 1979). Stomatal closure at high $\mathrm{SO}_{2}$ dose may be associated with accumulation of $\mathrm{CO}_{2}$ in the sub-stomatal cavities due to decline in photosynthesis. It has been reported that air pollution increases cell permeability by damaging the membrane integrity (Keller, 1986) more so in case of sensitive plant species (Forooq and Beg, 1980). Pollutants induced increased cell permeability may cause a loss of water from guard cells to make them flaccid, which results in stomatal closure. Further, encrustation or dust deposition on leaf cuticle due to particulate penetration in to the epicuticular wax may reduce the integrity of the incident light hampering photosynthesis which may, further lead to an accumulation of $\mathrm{CO}_{2}$ in to the sub-stomatal cavities and hence stomatal closure (Verma and Singh, 2006).

Air born particulate also causes stomatal clogging. Particles having diameters less than the diameters of stomata cause the partial clogging while those having equal diameters to that of stomata completely clogged them(Fluckiger et al., 1977; Fluckiger and Fluckiger-Keller, 1978). Hussain et al. (1989) reported stomatal clogging due to the cement dust and automobiles. Air born particulates reportedly decrease the number and size of stomata (Salgare and Chanderani, 1990; Sibek and Gulyas, 1990). Clogging and reduced size of stomata has impaired physiological function and affects the stomatal diffusive resistance (Addicot, 1986). This might have retarded the growth by causing a draught like condition in affecting plants. Ali et al. (2008) has reported that $1 \mathrm{ppm}$ of $\mathrm{SO}_{2}$ has 


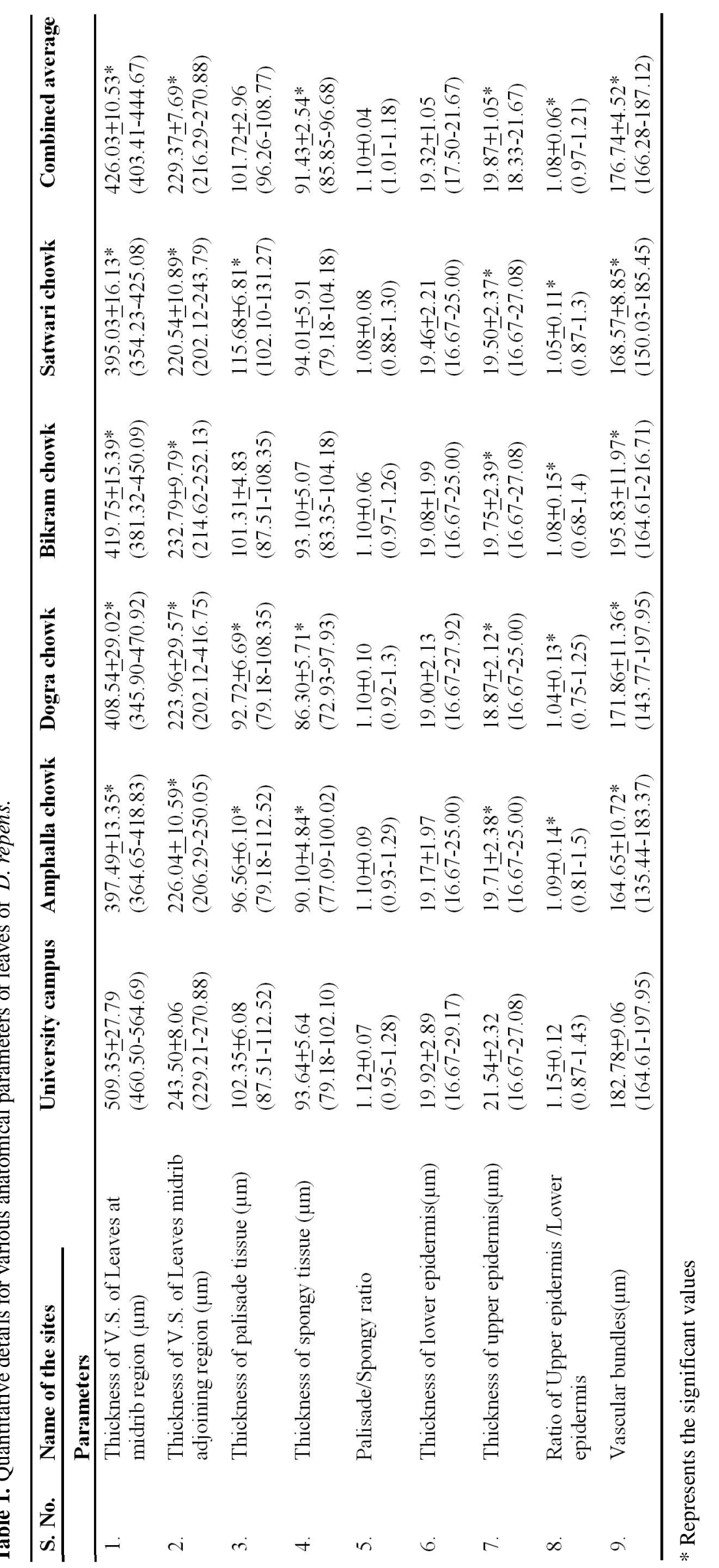




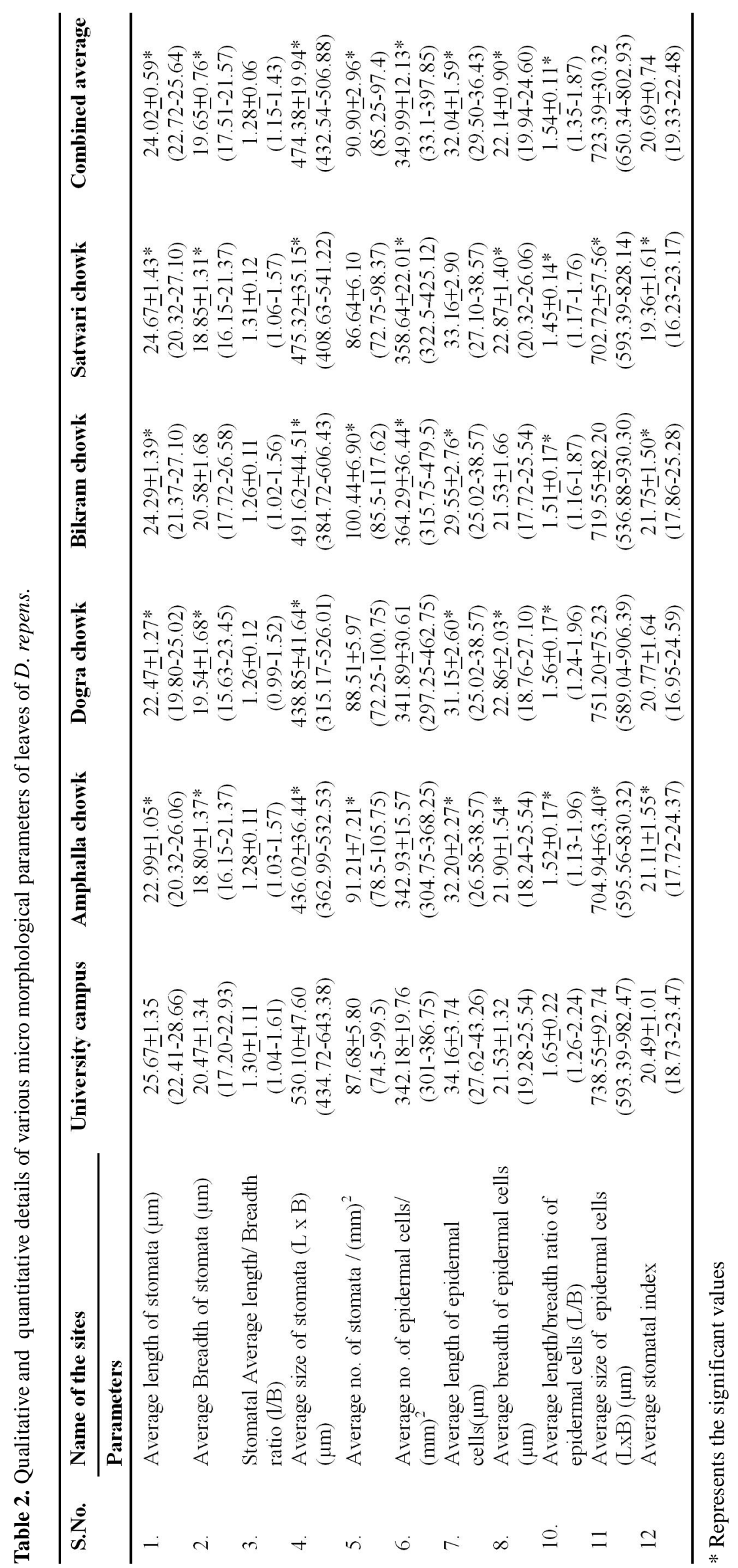




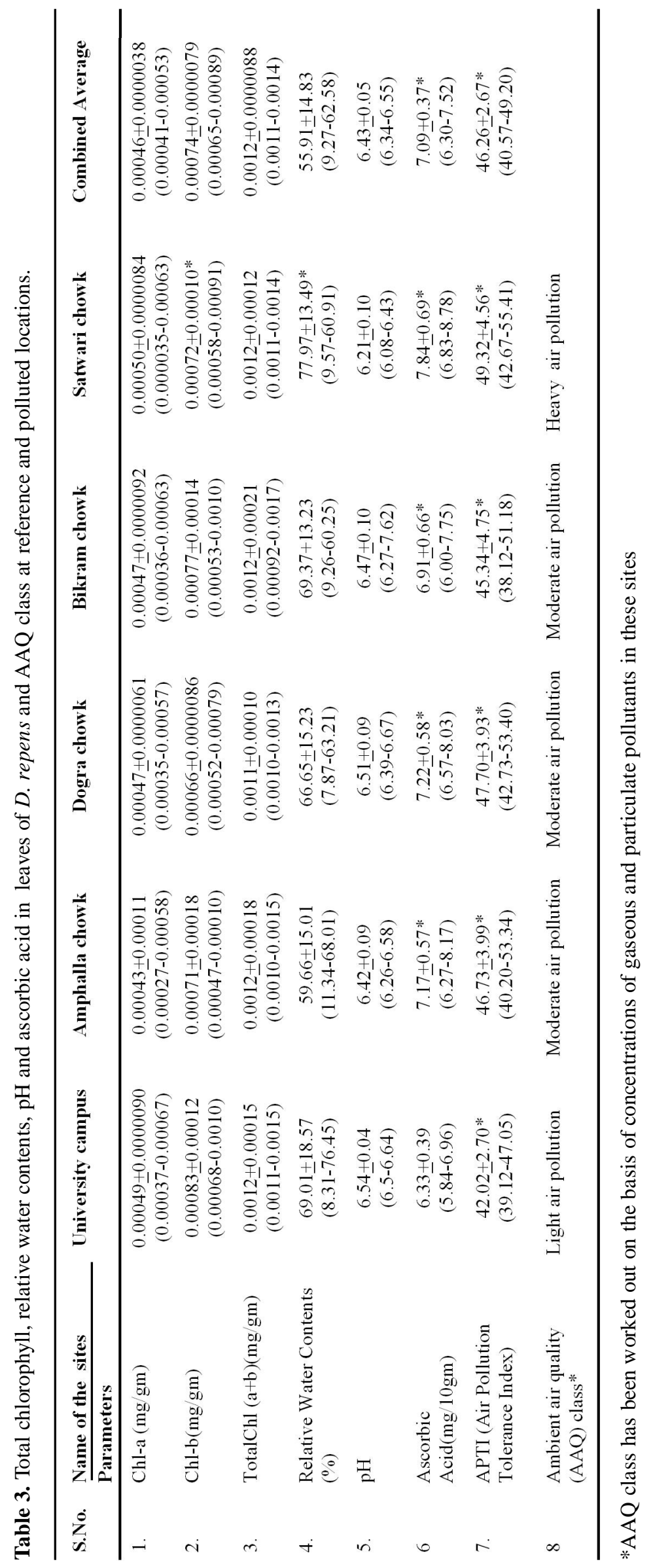


noticeable difference in aperture size while $0.5 \mathrm{ppm}$ of $\mathrm{SO}_{2}$ doesn't have any noticeable difference in aperture size.

Air pollution also interferes with the anatomy of the plants. Workers like Salgare and Rawal (1990); Salgare and Acharekar (1991); Swain (1994); Samal and Santra (2002) and Raina and Bala (2007) have reported the decrease in the anatomical parameters in the leaves of some plant species growing in the polluted areas. However, in genera like Syzygium cumini, all the anatomical parameters except upper and lower epidermis have been reported to get stimulated by air pollution (Raina and Sharma, 2003).

In the present study almost all the anatomical parameters such as thickness of the midrib region, midrib adjoining region, spongy tissue, upper epidermis, upper and lower epidermis ratio and vascular bundles decreases significantly whereas palisade/spongy tissue ratio, lower epidermis and palisade tissue remained unaffected (Table 2). The intercellular spaces of the plants facilitate more gaseous diffusion. However, the compactness of the leaves reduces the flux of the gases into the leave interior that may further result in poor performance of the plants. Photosynthesis is highly sensitive to air pollution; therefore measurement of chlorophyll in leaves is conceptually regarded as a useful diagnosis to determine the subtle pollutant effects. It is suggested that the pollutant gases such as $\mathrm{SO}_{2}, \mathrm{NO}_{2}$ and $\mathrm{O}_{3}$, produces oxyradicals in reaction with pollutants (Sakaki et al., 1983) which causes damage to the membrane and associated molecules including chlorophyll pigment.

Chlorophyll is the index of productivity (Bell, 1980) and synthesis or degradation of chlorophyll play a leading role in the tolerance of the plants to air pollution (Dedio, 1975). Hence higher the chlorophyll contents greater is the tolerance of plants to pollution. Rao and LeBlanc (1966) have reported the degradation of Chlorophyll b due to the formation of chlorophyllide as $\mathrm{SO}_{2}$ remove the phytol group of the chlorophyll $\mathrm{b}$ molecules. In the present study, concentration of Chlorophyll $\mathrm{b}$ has been observed to decrease significantly at Dogra and Satwari chowk (Table 3). This may be due to the higher level of pollution as has been reflected in terms of Air Quality Index (AQI) of these crossings (Table 3). Strand (1993) reported that photosynthetic pigment can also be affected at even low concentration of mixture of $\mathrm{SO}_{2}$ and $\mathrm{NO}_{2}$. Decrease in chlorophyll contents have been reported by Pandey and Pandey (1994), Agarwal (2000), Ramakrishnaiah and Somashekar (2003), and Kumari et al. (2005). However Karthiyayini et al. (2005) reported higher contents of chlorophyll in various plant species. Ascorbic acid is an antiscorbic vitamin and is reported to play an important role in $\mathrm{SO}_{2}$ reduction. It is a strong reductant and its reducing power is directly proportional to its concentration as suggested by Rao (1979). Its concentration influences many physiological and defense mechanism of plants, the synthesis as well as reducing activity of ascorbic acid is largely dependent on the $\mathrm{pH}$ of the cell. It also maintains the stability of plant cell membrane during stress (Dhindsha et al., 1982). Studies have indicated direct relationship between the endogenous level of ascorbic acid and plant susceptibility to air pollution (Chen et al., 1990). Therefore, it is obvious that higher concentrations of ascorbic acid protect the plants from $\mathrm{SO}_{2}$ toxicity and vice versa.

Concentration of ascorbic acid may increase (Sunitha and Rao, 1997; Agarwal, 2000; Karthiyayini et al., 2005) or decrease (Keller and Schwager, 1977; Sunitha and Rao, 1997; and Agarwal, 2000; Ramakrishnaiah and Somashekar, 2003) in different plant species depending upon their tolerance to the pollutants. In the present study, significantly higher concentration of ascorbic acid has been observed at polluted locations as compared to reference site (Table 3). This may increase the tolerance capacity of the $D$. repens against the higher level of pollutants in the environment.

Air Pollution Tolerance Index (APTI), calculated on the basis of total chlorophyll contents, relative water contents, $\mathrm{pH}$ and ascorbic acid content, reflects the tolerance capacity of the plants toward pollution. Plants with higher air pollution tolerance index (APTI) value are more capable to combat air pollution and can be used as sink to mitigate pollution, while plants having low index value show less tolerance and can be used to indicate levels of air pollution (Singh and Rao, 1983). Depending upon the sensitivity of the various plant species, higher values of APTI have been worked out for some plant species growing at polluted areas by various workers Keller and Schwager (1977); Raza et al. (1988); Datta and Ray (1995); Sunitha and Rao (1997); Agarwal (2000); Ramakrishnaiah and Somashekar (2003) and Karthiyayini et al. (2005) while in some other species decrease in APTI have been reported at polluted locations (Sunitha and Rao, 1997; Swami and Chauhan, 2007). Datta and Ray (1995) maintain that species having low index values are more sensitive to air pollution and vice versa.

The significant increase in the value of APTI at polluted locations (Table 3 ), in the present study indicates that $D$. repens is capable to combat air pollution and can be used as sink to mitigate pollution. Thus, it can be concluded that $D$. repens can be safely regarded as an ideal species for phytomonitoring of air pollution along the roadside in polluted habitat. Plantation of this species will also lead to rapid amelioration of habitat to cope up with polluted environment.

\section{REFERENCES}

Aberg, B. (1958). Ascorbic acid. In: H. Burstorm (Ed.), 
Encyclopedia of plant physiology, 6:479-497.

Addicot, F.T. (1986). Environmental factors in the physiology of abscission. PI. Physiol., 43: 1471-1479.

Agarwal, M. (2000). Plants as biomonitors of air pollution. In: M.Yunis. P.S. Srivastava and T.O. Siddiqui (Ed.), Environmental Hazards - Plants and people.CBS Publishers, New Delhi. pp. 404.

Aggarwal, P. (2000). The effect of auto exhaust pollution on leaf surface of Cassia siamea (L.) - a road side tree. Acta Ecol., 22:2.

Ali, S.T., Mahmooduzzafar, Abdin, M.Z. and Iqbal M. (2008). Ontogenetic changes in foliarfeatures and psoralen content of Psoralea corylifolia Linn. exposed to $\mathrm{SO}_{2}$ stress. J. Environ. Biol., 29(5): 661-668.

Bell, J. N. B. (1980). Response of plants to sulphur dioxide. Nature Lond., 284: 399-400

Bhiravamurthy, P.V. and Kumar, P.V. (1983). Air pollution and epidermal traits of Calotropis gigantia (Linn.). R.Br. Ind. J . Air Poll. Cont., 1: 23-26.

Chaudhari, G.N., Rao, N.V. and Inamadar, J.A. (1984). Effects of air pollution on leaf epidermal and architecture of Lycopersicon lycopersicum krast, Var. angurlata. Indian J . Environ. HIth., 26: 238-243.

Chen, Y. M., Lucas, P.W. and Wellburn, A.R. (1990). Relationships between foliar injury and changes in antioxidant levels in red Norway spruce exposed to acidic mists. Environ. Pollut., 68:1-15.

Dedio., W. (1975). Water relations in wheat leaves as screening tests for drought resistance. Can. J. Plant Sci., 55: 369-378.

Dhindsha, R.S., Dhindsha, P. P. and Thorpe, T.A. (1982). Leaf senescence: Correlation with increase levels of membrane permeability and lipid peroxidation and decreased levels of super oxide dismutase and catalase. J . Exp. Bot., 32: 91-101.

Datta, S.C. and Ray, S.S. (1995). APTI value of five different species of higher plants from the metropolis of Calcutta. In: D.D. Chawan (Ed.), Environmental and adaptive biology of plants.Scientific publishers. Jodhpur, pp. 289-294.

Forooq, M. and Beg, M.U. (1980). Effect of aqueous sulphur dioxide on the membrane permeability of common Indian tree leaves. New Botanist, 7 :213-217.

Fluckiger, V.W., Keller, H. F., Oertli, J. J. and Guggenheim, H. (1977). Pollution on leaf and needle surfaces near high way and its effect on stomatal diffusive resistance. Eur. J . For. Path, $7: 358-367$.

Fluckiger, W. and Keller, H. F. (1978). Changes in Contents of beta-carotene, vitamine: "C" in parsley in the vicinity of a high way. Qual. Plants. PI. F ds. H um. Nutr, 28 :1-9.

Gupta, S., Bhattacharjee, D., Datta, J.K., Nayek, S. and Satpati, S. (2009). Effect of vehicular lead emissions on biochemical constituents of leaves. Poll. Res., 28 (2) : 157-160.

Hiscox, J. D. and Israelstam, G. F. (1979). A method for the extraction of chlorophyll from tissue without maceration. Can. J. Bot, $57:$ 1332-1334.

Hussain, F., Ilahi, I. and Rashid, I. A. (1989). Effect of cement dust on the chlorophyll contents, stomatal clogging and biomass of some selected plants. Pak. J. Sci. Ind. Res, 32: 542-545.

Jhar, A.K. (1988). Environmental modification of leaf surface traits as induced by pollutants resulting from fossil fuel firing. Environ. Ecol., 6: 781-782.
Karthiyayini, R., Ponnammal, N.R. and Joseph, R. (2005) Air pollution tolerance index of Certain plants of Coimbatore- Ooty highways, near ITI area, Coimbatore, Tamilnadu. Poll Res, 24(4) :801-803.

Kaur, S. (2004). Stomatal responses of lemon (citrus medica) to exhaust emissions from vehicles using different types of fuel. Poll. Res., 23 (3) : 451-454.

Keller, J. and Schwager, H. (1977). Air pollution and ascorbic acid. Env. J . F orests Pathol, $7: 338-350$.

Keller, T. (1986). The electrical conductivity of Norway spruce needle diffusate as affected by air pollutants. Tree Physiol, 1: 85-94.

Khergamker, G. (2011). Manage traffic to reduce pollution. In: Times of India, NewDelhi- Chandigarh Edition, $23^{\text {rd }}$ June, 62 (147): 9.

Krishnamurthy, K.V. and Rajachidambaram, C. (1980). Histological response of plants to atmospheric pollution, $A$ review. Biology, 2: 8-13.

Kumar, N. and Jaishree (1989). Effect of railway tract air pollution on epidermal features of $\mathrm{G}$ omphrena celosiodes Mart. Adv. Plant Sci, 2 (1): 54-57.

Kumari, S.I., Rani, P.U. and Suresh, C.H. (2005). Absorption of automobile pollutants by leaf surfaces of various road side plants and their effect on plant biochemical constituents. Poll Res, 24 (3) : 509-512.

Maury, A.N., Usha and Gupta, R.K. (1989). Responses of Indian Jujuba (Zizyphys jujub Lamk.) to coal smoke pollution. Geobios, 16(5) : 229-231.

Morison, J.I.L. (1998). Stomatal response to increased $\mathrm{CO}_{2}$ concentration. J . of Experimental Botany, 443-452.

Noland, T.L. and Kozlowski, T.T. (1979). Effect of $\mathrm{SO}_{2}$ on stomatal aperture and sulfur uptake of wood angiosperm seedlings. Can. J. Forest Res, 9: 57-62.

Pal, A., Kulshreshtra, K., Ahmed, K.J. and Junus, M. (2000). Changes in leaf surface structures of two tree species caused by autoexhaust pollution. J. Environ. Biol, 21 (1) : 15-21.

Palaniswamy, M., Gunamani, T. and Swaminathan, K. (1995). Effect of air pollution caused by automobile exhaust gases on crop plants. Proc. Acd Environ. Biol., 4 (2) : 255-260.

Pandey, J. and Pandey, U. (1994). Evolution of air pollution phytotoxicity in a seasonally dry tropical urban environment. Envir on. M onit. Assess., 33 (3) : 195-213.

Pratibha and Sharma, M. (2000). Changes In chlorophyll and total free amino acids of gram in response to sulphur dioxide exposure under field conditions. Poll. Res., 19 (1) : 95-97.

Raina, A.K. and Sharma, A. (2003). Effect of vehicular pollution on the leaf micro-morphology, anatomy and chlorophyll contents of Syzygium cumini L. IJ EP, 23.(8) : 897-902.

Raina, A.K. and Sharma, A. (2006). Assessment of air pollution and its impact on the leaves of some plant species. Poll. Res., 25 (3): 543-547.

Raina, A.K. and Aggarwal, B. (2004). Effect of vehicular exhaust on some trees in Jammu-II. J . of Industrial Pollution Control, 20.(2) : 229-232.

Raina, A.K. and Bala, C. (2007). Effect of vehicular pollution on Polyalthia Iongifolia Benth. \& HK.f. and I pomoea cairica (L.) Sweet in Jammu, J\&K. Environment \& E cology, 25S (4): 1103-1109.

Ramakrishnaiah, H. and Somashekar, R.K. (2003). Higher plants as biomonitors of automobiles pollution. Eco.Env. 
and Cons, 9 (3) : 337-343.

Rao, D. N. and LeBlanc, F. (1966). Effects of $\mathrm{SO}_{2}$ on the lichen alga with special reference to chlorophyll. Bryologist, 69: 69-75.

Rao, D. N. (1979). Plant leaf as pollution monitoring device. Fertilizer News May, 25-28.

Raza, S.H., Kumar, V. and Murthy, M.S.R. (1988). Air pollution tolerance index of certain plants of Nacharam industrial area. Hyderabad. Indian J. Bot., II (1) : 91-95.

Sakaki, T., Kondo, N. and Sugahara, K. (1983). Breakdown of photosynthetic pigments and lipids in Spinach leaves with ozone fumigation. Role of activated oxygen. Physiol. Plant, 59: 28-34.

Salgare, S. A. and Iyer, M. P. (1991). Effects of auto-exhaust pollution on the micromorphology of some weeds. In: S.k Agarwal (Ed.), Automobile pollution. New Delhi: Ashish Publishing House.pp119-134

Salgare, S. A. and Swain, S. (1991). Effect of autoexhaust pollution at Western Express Highway near National Park, Boriveli (East) on the micromorphology of some weed (1Harvest). J. Biosphere, 3 (1): 8-18.

Salgare, S.A. and Chanderani, A. (1990). Effect of Industrial air pollution from chamber on microbiology of some wild plants. Adv.Plant Sci, 3: 1.

Salgare, S.A. and Acharekar, C. (1991). Effect of ambient air on the leaf anatomy of some wild plants-1. Environ. Biol., 12 (4) : 347-352

Salgare, S.A. and Rawal, M. (1990). Effect of auto-exhaust pollution at Andheri (west), Bombay on the anatomy of some cultivated plants (monsoon season). J. E cobiol., 2 (4) : 273-280.

Samal, A.C. and Santra, S.C. (2002). Air quality of Kalyani Township (Nadia, West Bengal) and its impact on surrounding vegetation. Indian J. Environ. HIth, 44(1) : 71-76.

Saxena, L.M. (1985). Air pollution induced changes in foliar pigment and ascorbic acid content in Bougainvillia spectabilis Wild. and Cassia siama Linn. Acta Eco, 7 (1) : 20-24.
Sharma, G.K. and Butler, J. (1975). Envirronmental pollution: Leaf cuticular Patterns in Trifolium pratense L. Ann. B ot., 39: 1089-1090.

Sibek, S. and Gulyas, S. (1990). Leaf anatomical changes in perishing acaluous oak. Acta B oil., 36: 23-52.

Singh, A. (1977). Practical plant physiology. Kalyani publishers.New Delhi.

Singh, S.K. and Rao, D. N. (1983). Evaluation of plants for their tolerance to air pollution. Proc. Symposium on air pollution control. Indian association for air pollution control. New Delhi. I: 218-224.

Strand, M. (1993). Photosynthetic activity of Scot pine (Pinus sylvestris L.) needles during winter is affected by exposure to $\mathrm{SO}_{2}$ and $\mathrm{NO}_{2}$ during summer. New Phytol, 23 : 133-141.

Sunitha, M. and Rao, K.V.M. (1997). Air pollution tolerance capacities of selected plant species. J . Indian Bot. Soc, 76 : 95-98.

Swami, A. and Chauhan, D. (2007). Air pollution tolerance index of few plant species affected by auto exhaust pollution around Haridwar. Environment Conservation J ournal, 8(3) : 9-11.

Swain, S. (1994). Effect of autoexhaust pollution at Western Express Highway near National Park, Boriveli (East) Bombay on the leaf anatomy of some weed. (1- Harvest). Int. J. Mendel, 11 (1and2) : 61-63.

Verma, A. and Singh, S. N. (2006). Biochemical and ultrastructure changes in plant foliage exposed to autopollution. Environ. M onit. Assess., 120 : 585-602.

Wagoner, S. (1975). Leaf cuticular and morphological variations in Plantago lanceolata as indicators of environmental pollution. J .Tennessee Acad. Sci, $50: 79-83$.

Yunus, M., Kulshreshtha, K., Dwivedi, A.K. and Ahmad, K.J. (1982). Leaf surface traits of Ipomoea fistulosa Mart. Ex. Choisy as indicators of air pollution. New Botanist, 9 : 39-45. 